\title{
Analysis of HIV-1 gp120 quasispecies suggests high prevalence of intra-subtype recombination
}

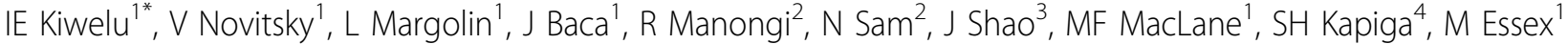 \\ From AIDS Vaccine 2012 \\ Boston, MA, USA. 9-12 September 2012
}

\section{Background}

Recombination between viruses of the same HIV-1 subtype has been understudied primarily due to the lack of reference sequences, as well as appropriate bio-informatics tools. The introduction of recombination detection program (RDP3) made the detection of HIV-1 intra-subtype recombination feasible.

\section{Methods}

This study determined the prevalence and patterns of HIV-1 intra-subtype recombinants among female bar and hotel workers in Moshi, Tanzania. The HIV-1 env gp120 V1-C5 quasispecies from 45 subjects classified as pure HIV-1 subtypes A1, C, or D were analyzed for recombination events by RDP3.

\section{Results}

HIV-1 quasispecies with evidence for recombination were found in $89 \%$ of subjects infected with pure HIV-1 subtypes A, C, and D. Recombinant viruses were observed at both the baseline and the 12 month visits in $88 \%$ of the subjects; in $12 \%$ of subjects recombination was identified only at the later time point. Two major patterns were observed: $70 \%$ of subjects had unique recombination breakpoints without dominance of any particular variant, while in $30 \%$ of subjects a specific recombinant variant dominated in the pool of viral quasispecies.

\section{Conclusion}

A large proportion of female bar and hotel workers were infected with intra-subtype recombinant viruses. These results suggest that HIV-1 co- and super-infections are common in this population, and occur more frequently than previously thought. Intra-subtype recombination

${ }^{1}$ Harvard School of Public Health, Boston, MA, USA

Full list of author information is available at the end of the article contributes to the increased viral diversity which poses a challenge to HIV-1 vaccine design.

\section{Author details}

${ }^{1}$ Harvard School of Public Health, Boston, MA, USA. ${ }^{2}$ Kilimanjaro Christian Medical College, Moshi, Tanzania, United Republic of. ${ }^{3}$ Kilimanjaro Medical Christian College, Moshi, Tanzania, United Republic of. ${ }^{4}$ London School of Hygiene and Tropical Medicine, London, UK.

Published: 13 September 2012

doi:10.1186/1742-4690-9-S2-P146

Cite this article as: Kiwelu et al: Analysis of HIV-1 gp120 quasispecies suggests high prevalence of intra-subtype recombination. Retrovirology 2012 9(Suppl 2):P146.
Submit your next manuscript to BioMed Central and take full advantage of:

- Convenient online submission

- Thorough peer review

- No space constraints or color figure charges

- Immediate publication on acceptance

- Inclusion in PubMed, CAS, Scopus and Google Scholar

- Research which is freely available for redistribution
() Biomed Central 